\title{
Non-pharmacological measures in the pain management in newborns: nursing care
}

\author{
Medidas não farmacológicas no manejo da dor em recém-nascido: cuidado de enfermagem
}

Ana Paula da Silva Morais ${ }^{1}$, Silvania Moreira de Abreu Façanha ${ }^{1}$, Sarah Nogueira Rabelo ${ }^{1}$, Ana Valeska Siebra e Silva $^{1}$, Maria Veraci Oliveira Queiroz ${ }^{1}$, Edna Maria Camelo Chaves ${ }^{1}$

Objective: to analyze the evidence of the literature about pain management during arterial puncture, venous and capillary in the newborn that received non-pharmacological measures before the painful procedure. Methods: this is an integrative review performed in databases. Initially, 120 articles were selected being a sample composed of ten articles. Data were collected in forms. Results: orally glucose was the most used method followed by breast milk and contact measures and the use of glucose associated or not to breast milk and contact measures. Conclusion: the use of non-pharmacological methods has been proven effective to promote the relief of pain in newborns.

Descriptors: Infant, Newborn; Nursing; Pain; Blood Vessels; Glucose.

Objetivo: analisar as evidências da literatura sobre o manejo da dor durante a punção arterial, venosa e capilar no recém-nascido que receberam medidas não farmacológicas antes do procedimento doloroso. Métodos: revisão integrativa realizada em bases de dados. Inicialmente, selecionados 120 artigos, sendo amostra composta de dez artigos. Dados coletados em formulário. Resultados: a glicose por via oral foi o método mais utilizado, seguido do leite materno e medidas de contato e o uso da glicose associado ou não com leite materno e medidas de contato. Conclusão: o uso de métodos não farmacológicos tem se mostrado eficaz para promover o alívio da dor em neonatos.

Descritores: Recém-Nascido; Enfermagem; Dor; Vasos Sanguíneos; Glucose.

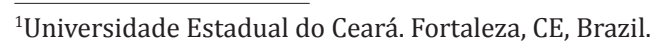




\section{Introduction}

The newborn pain results from procedures performed during hospitalization in the neonatal unit including punctures to collect laboratory examinations, common in clinical nursing practice.

The pain felt by the newborn has been studied in recent years through the risk of possible neurological and behavioral changes that painful experiences produces about development ${ }^{(1)}$. This fact has aroused concern in the multidisciplinary team that provides care to newborns in neonatal units, particularly in the nursing team that performs these punctures.

Studies in animals and newborn show that the reaction to painful stimulus, repeated, and prolonged episodes may cause consequences on cognitive and neurobehavioral development in a medium and long$\operatorname{term}^{(2)}$.

It is known that newborns undergo many painful daily stimuli during the period of hospitalization, such as: intubation, aspiration of the tracheal tube, sample collection by arterial puncture, venous access, chest drainage, among others ${ }^{(3)}$. It is estimated that during this period of hospitalization in the neonatal intensive care unit, newborns receive about 50 to 150 potentially painful procedures per day ${ }^{(4)}$. This can vary according to the clinical status of the patient, the duration of hospitalization, as well as the exposure to an external stimulus, such as intense and continuous light, temperature and noise.

Nursing performs most invasive procedures for newborn recovery during hospitalization. These procedures are the main sources of pain, and the nurse has great responsibility in preventing/minimizing the pain in their patients ${ }^{(5)}$. These actions should be a priority during the neonatal care as well as the improvement of scientific knowledge for carrying out the procedures.

The intensive effort of health professionals to save lives at serious risk has inhibited the perception that it is also possible to simultaneously reduce their suffering ${ }^{(6)}$. Although it is known that an important part of pain experienced by the newborn can be prevented or substantially relieved, is still observed a little use of relief methods and pain prevention in newborns during painful procedures.

The identification of situations that can be stressful for newborns admitted to the neonatal intensive care unit is important, as they influence their normal development. One of the fundamental methods is the adequate evaluation of pain in newborns since it depends on the remedial measures to control pain and minimizing suffering ${ }^{(7)}$.

This becomes a challenge due to the impossibility of verbal communication between professionals and newborns. It is said that proper assessment of pain is important because, depending on the result, there is the decision-making, especially regarding the implementation of analgesic measures as pain assessment requires professional skills and experience, plus knowledge ${ }^{(8)}$.

Thus, behavioral and physiological criteria are used to measure the intensity of pain, such as the Neonatal Facial Coding System, the Neonatal Infant Pain Rating Scale, the Premature Infant Pain Profile, Visual Analogue Scale, among others ${ }^{(9)}$.

Nursing professionals should use these tools to systematically assess the pain presence in the newborn during procedures to develop prevention, reduction and elimination ${ }^{(10)}$. To this end, pharmacological and non-pharmacological methods can be used.

The pharmacological strategies are indicated for severe and intense pain, usually caused by invasive procedures, prolonged, more complex, include the use of opioids, local anesthetics, and glucose intake at $25.0 \%$, and others ${ }^{(10)}$. Non-pharmacologic interventions have been recommended for relief and pain management during procedures related to the acute pain of mild to moderate intensity. They have proven the efficiency and present low risks to babies, as well as low operating cost concerning intensive care. Methods as non-nutritive sucking, glucose solution, breastfeeding, kangaroo position, music therapy, massage therapy, among others can be used ${ }^{(11)}$. 
Considering that drug therapy for pain relief may have some adverse effects and jeopardize the development of the newborn, the use of nonpharmacological measures is beneficial, and studies are proving its effectiveness ${ }^{(3.7)}$. Thus, the literature review contributes to nursing clinical practice showing evidence on the management of newborn pain in arterial, venous and capillary punctures because systematizing this knowledge; this will serve to guide clinical practice providing improved life of babies under nursing care in a neonatal unit.

The aim of the study was to analyze the evidence of the literature about pain management during arterial, venous and capillary puncture in the newborn that received non-pharmacological measures before the painful procedure.

\section{Methods}

This is an integrative review, research method that summarizes results of literature research through a process of systematic analysis following the steps: elaboration of the research question; literature search of primary studies based on inclusion and exclusion criteria; organization of pre-selected studies (data extraction of primary education); critical analysis of selected primary studies; analysis and synthesis of the evaluated results; presentation of the integrative review ${ }^{(12)}$.

The search period was from 2006 to 2015, with the following keywords: Newborn; Nursing; Pain; Blood vessels; Glucose, and the main question: which are the evidence of the literature about pain managementand which were the non-pharmacological measures used before arterial, venous and capillary punctures in newborns?

The searched databases were Scopus Info Site (SCOPUS), US National Library of Medicine (PUBMED) and Literatura Latina-Americana e do Caribe em Ciências da Saúde (LILACS). In the first search 120 articles were found, SCOPUS with 70 articles, PUBMED 32 articles and 18 articles in LILACS (Figure
1). Followed by reading the summary noting the inclusion criteria: full-text articles available in English, Portuguese, and Spanish that addressed the use of non-pharmacological measures before the puncture procedures. The exclusion criteria were: being theses and dissertations, editorials and review studies. The scale was used to classify the evidence level ${ }^{(13)}$.

\begin{tabular}{|l|c|c|c|c|}
\hline Intercrossing & $\begin{array}{c}\text { SCOPUS } \\
\text { Infant/Nurs- } \\
\text { ing/Glucose/ } \\
\text { Pain }\end{array}$ & $\begin{array}{c}\text { LILACS } \\
\text { Newborn/ } \\
\text { Pain/Nurs- } \\
\text { ing/Glucose }\end{array}$ & $\begin{array}{c}\text { PUBMED } \\
\text { Infant/Nurs- } \\
\text { ing/ucose/ } \\
\text { Pain }\end{array}$ & Total \\
\hline Found productions & 70 & 18 & 32 & 120 \\
\hline $\begin{array}{l}\text { Excluded because it does } \\
\text { not address the issue }\end{array}$ & 51 & 8 & 17 & 76 \\
\hline Review articles & 2 & 2 & 6 & 10 \\
\hline $\begin{array}{l}\text { Does reports } \\
\text { interventions }\end{array}$ & 8 & - & 5 & 13 \\
\hline Repeated & 5 & 3 & 3 & 11 \\
\hline Total selected & 4 & 5 & 1 & 10 \\
\hline
\end{tabular}

Figure 1 - Strategy of search and numbers found in databases

For critical evaluation, the reading of the studies was held in full and the reading of the results, with the purpose to identify relevant aspects that were repeated or highlighted. Articles were identified by numbers, according to the order of location and organized in a bibliographic record with the following items: databases, year, country, authors, journal, type of study, the level of evidence, title, nonpharmacological measures, and results.

\section{Results}

There was similarity of the studies in SCOPUS and LILACS database with five articles each, followed by an article, and one PUBMED article which was in the SCOPUS database.

The year with the highest number of publications on the subject was in 2011, with three 
articles, followed by 2009 and 2010, with two articles. Brazil was the country that most published, with five articles, followed by Australia with two articles. The magazines with the largest number of publications were Anna Nery School, Pediatric Nursing Magazine with two publications each, three studies with a quantitative approach, one randomized clinical trial and two randomized and controlled studies. The level of evidence that most appeared was the level IV, with five articles, followed by level II with four and level III with one (Figure 2).

\begin{tabular}{|c|c|c|c|}
\hline Article & Title & $\begin{array}{l}\text { Non-pharmacological } \\
\text { measure }\end{array}$ & Results \\
\hline 01 & $\begin{array}{l}\text { Music and } 25.0 \% \text { glucose in relief } \\
\text { of premature pain: clinical and } \\
\text { randomized trial }\end{array}$ & Music and $25.0 \%$ glucose & $\begin{array}{l}\text { The results show that } 60 \% \text { of premature had moderate or severe pain, pain } \\
\text { scores, and intervention groups were not statistically significant. }\end{array}$ \\
\hline 02 & $\begin{array}{l}\text { The use of oral sucrose for pain before } \\
\text { procedures in breastfeeding up to six } \\
\text { months: a randomized and controlled } \\
\text { trial }\end{array}$ & $\begin{array}{l}\text { Sucrose } 25.0 \%(2 \mathrm{ml}) \text { or } \\
\text { sterile water }\end{array}$ & $\begin{array}{l}\text { There was no statistical difference in minimizing pain when compared to the } \\
\text { control group. }\end{array}$ \\
\hline 03 & $\begin{array}{l}\text { The care by nurses to premature } \\
\text { Newborns in front of venipuncture }\end{array}$ & $\begin{array}{l}\text { Glucose, } \quad \text { confortable } \\
\text { positioning, lullaby, and } \\
\text { warmth }\end{array}$ & $\begin{array}{l}\text { The care provided by nurses were known, to reduce and control pain in the } \\
\text { premature newborn submitted to venipuncture. }\end{array}$ \\
\hline 04 & $\begin{array}{l}\text { Implementing measures for the relief } \\
\text { of pain in neonates by the nursing } \\
\text { team }\end{array}$ & $\begin{array}{lrr}\text { Gauze } & \text { pacifier } & \text { with } \\
\text { glucose, } & \text { lullaby, } & \text { and } \\
\text { packet } & & \end{array}$ & $\begin{array}{l}\text { The interviewees demonstrated to know the beneficial effect of glucose for } \\
\text { the neonate and implement strategies that, applied together before painful } \\
\text { procedures, provide relief and relaxation for the baby. }\end{array}$ \\
\hline 05 & $\begin{array}{l}\text { Breast milk and glucose for pain relief } \\
\text { in premature }\end{array}$ & $\begin{array}{l}\text { Breast milk versus glucose } \\
(25.0 \%)\end{array}$ & $\begin{array}{l}\text { Similar groups regarding demographic and clinical characteristics. Lower } \\
\text { pain scores in the control group over three minutes after the puncture } \\
(\mathrm{p}<0.001) \text {. A larger number of control group children presented Premature } \\
\text { Infant Pain Profile scores, indicative of minimal pain or absence of pain } \\
(\mathrm{p}<0.002 \text { and } \mathrm{p}<0.003) 30 \text { seconds after lancing and the average difference } \\
\text { in scale scores were } 3 \text { ( } 95 \% \text { confidence interval: } 1.507 \text { to } 4.483 \text { ). Crying low } \\
\text { incidence ( }<<0.001 \text { ) and shorter duration of crying ( }<<0.014 \text { ) were observed } \\
\text { in the control group. Adverse events without significance. }\end{array}$ \\
\hline 06 & $\begin{array}{l}\text { Analgesic effect of breast milk versus } \\
\text { sucrose analgesic during jump bid in } \\
\text { late premature what is known about } \\
\text { this issue: breastfeeding and oral }\end{array}$ & $\begin{array}{l}\text { Breast milk versus sucrose } \\
\text { solution }\end{array}$ & $\begin{array}{l}\text { There was no significance in mean scores between Premature Infant Pain } \\
\text { Profiles, neonates receiving breast milk (6.1) or sucrose (5.5) with a mean } \\
\text { difference of } 0.6 \text { ( } 9.5 \% \text { confidence interval of } 21.6 \text { to } 2.8 ; p>0.58)\end{array}$ \\
\hline 07 & $\begin{array}{l}\text { The effects of various interventions for } \\
\text { newborns about pain and duration of } \\
\text { crying }\end{array}$ & $\begin{array}{l}\text { Milk, sucrose and pacifiers } \\
\text { and the mother's contact } \\
\text { to overcome the pain } \\
\text { and duration of crying }\end{array}$ & $\begin{array}{l}\text { No difference was determined between among the groups for heart rate } \\
\text { and oxygen saturation in newborns during painful interventions }(\mathrm{P}>0.05) \text {. } \\
\text { Sucrose followed by pacifier was the most effective method to reduce crying } \\
\text { time in newborn. }\end{array}$ \\
\hline 08 & $\begin{array}{l}\text { Neonatal pain: non-pharmacological } \\
\text { measures used by the nursing staff }\end{array}$ & $\begin{array}{l}\text { Contention, non-nutritive } \\
\text { sucking, oral glucose, lap } \\
\text { and winding }\end{array}$ & $\begin{array}{l}\text { For non-pharmacological measures used by nursing professionals, most used } \\
\text { as main measures to contain, the non-nutritive sucking, oral glucose, lap and } \\
\text { winding. }\end{array}$ \\
\hline 09 & $\begin{array}{l}\text { Pain suffered by the newborn during } \\
\text { arterial puncture }\end{array}$ & $\begin{array}{l}25.0 \% \text { glucose and dis- } \\
\text { tilled water }\end{array}$ & $\begin{array}{l}\text { In the inferential analysis, the average pain intensity with distilled water was } \\
6.08 \text {; with glucose at } 25 \% \text { was } 1.04 \text {. Behavioral changes varied significantly, } \\
\text { and the physiological little have changed. }\end{array}$ \\
\hline 10 & $\begin{array}{l}\text { The effect of a familiar smell in } \\
\text { the behavioral and physiological } \\
\text { responses pain in neonates }\end{array}$ & $\begin{array}{l}\text { Vanillin flavor on a gauze } \\
\text { pad kept next to the nose } \\
\text { of the newborn }\end{array}$ & $\begin{array}{l}\text { The results of this study showed a strange smell, and vanillin did not reduce } \\
\text { the crying duration compared to the control group. }\end{array}$ \\
\hline
\end{tabular}

Figure 2 - Description of the selected articles 
It was observed that most of the articles carried over more than one non-pharmacological measure. Thus, it was found about seven different nonpharmacological measures (glucose, breast milk, nonnutritive sucking, skin to skin contact, positioning, music and smells). There was a predominance of the use of oral glucose, breast milk and contact measures and the use of glucose was associated or not with breast milk and contact measures. The use of glucose was the most frequent, associated or not to breast milk and contact measures.

\section{Discussion}

The small amount of articles about minimizing the pain before the venous, arterial and capillary puncture procedure is considered as a limitation of the study, as these aspects may have influenced the size of the sample. As for the time frame, it is believed that had no significant interference since the studies of non-pharmacological measures for pain relief in newborns are more recent, concentrated in recent years.

The study brings contributions to the scientific and practical field, as the dissemination of studies about the use of non-pharmacological methods in reducing and/or pain relief in newborn, comes to stimulate professionals and especially the nurse to use such measures in clinical practice. It also encourages the need for more studies with strong evidence about the beneficial effects of this therapy in the newborn care, which should be developed with a basis in scientific evidence.

In the analyzed publications, it can be shown that the use of non-pharmacological measures before the painful puncture procedures is becoming a care strategy to be held in newborns and breastfeeding in hospitals. It is known that the pain suffered by the newborn brings organic repercussions that can compromise their development.

This study contributes to the clinical practice of health staff, particularly nurses, who perform most painful procedures. The use of non-pharmacological measures to minimize pain, is important in the neonatal period, as drug therapy has many adverse effects due to the immaturity of organ systems of the newborn.

The pain in the premature newborn is a phenomenon that causes pain and discomfort. In recent decades due to the approach of human assistance, this matter has aroused the interest of health professionals, especially nurses, to identify and minimize newborns pain. And studies have now demonstrated that newborns have capacity equal or more intense biological responses to pain than older children and adults ${ }^{(14)}$.

The presence of pain is identified by some aspects presented by the newborn because of the impossibility of verbal communication. They are behavioral aspects such as pain, crying, breathing movements, limbs movements, alertness; and physiological as pulse, heart and respiratory frequency, oxygen saturation level, blood pressure, among others ${ }^{(15)}$.

In a study to assess whether the professional are aware of the pain presented by the newborn, they showed that they had necessary knowledge about the care to make less painful, invasive procedures for their achievement. Moreover, it is also important that nurses be careful and attentive in its realization, to minimize errors and need to make again the procedures ${ }^{(16)}$.

Thus, newborns diagnosed with diseases that become clinically unstable and due to this need intensive care, are then exposed to various painful procedures. Then there is the need for analgesia action during this invasive behavior, as it is believed in the effectiveness of non-pharmacological methods to provide minimization of this painful experience ${ }^{(17)}$.

The pain felt by the newborn should be minimized because stressful situations are present during hospitalization. The nurse, by performing the punctures in the newborn is a professional who can provide a differentiated assistance during painful procedures providing non-pharmacological measures. The pain can be minimized when strategies are 
used before the painful procedures. The act of sucking pacifiers with glucose, breast milk, contact measures, odors exposure are described as pain relief measures. Glucose is one of the substances used in the studies. It is recommended to make gauze pacifier with glucose two minutes before the procedure ${ }^{(3)}$.

The search for new strategies has led researchers to test new interventions. The use of music and $25.0 \%$ glucose was tested in a randomized clinical trial, with $60.0 \%$ of newborns undergoing invasive procedures showed some level of pain, ranging from mild to intense, but those who underwent music intervention and $25.0 \%$ glucose or glucose, it was observed that the association of music and glucose obtained lower pain scores than others used ${ }^{(18)}$.

In another study, we sought to demonstrate the analgesic effect of glucose and breast milk, and both confirmed this effect. The association of the two non-pharmacological measures showed a higher effect $^{(19)}$. Using the Premature Infant Pain Profile scale to measure neonatal pain can be confirmed minimization using glucose at $25.0 \%$, higher than the effect of breast milk during heel punch ${ }^{(20)}$.

Glucose has been used as a positive control in studies. One hundred and twenty newborn participated in a study in Turkey and checked the effect of the pacifier with gauze with milk or sucrose during painful procedures, comparing crying timerelated to pain. It was observed less fluctuation in the heart rate in sucrose group during and after the procedure, less weeping, and therefore, fewer hearts beats. Comparing the two substances the sucrose has performed better in promoting pain relief ${ }^{(15)}$.

The care provided with quality by nursing professionals is perceived when there is concern about the use of non-pharmacological measures, carried out before invasive procedures such as the use of pacifiers dipped with glucose, lullaby, breast milk, among others. Studies have shown that the use of these measures depended on the knowledge of professionals about the effectiveness of these methods, and especially the use of protocols in the institution $^{(10,21)}$. In the hospital, it was reported that in addition to identifying the nurse's knowledge, proved to be the assistance provided for reduction and pain management in premature newborn undergoing venipuncture $^{(16)}$. Knowledge holder nurses use nonpharmacological measures in their practice before painful procedures, especially punctures.

It is noteworthy that other substances begin to be used to relieve pain. The vanillin flavor and odor of breast milk were tested and observed up through behavioral and physiological parameters decreased crying time, decreased heart rate and oxygen level stabilization $^{(22-23)}$.

The use of non-pharmacological measures has emerged as therapeutic strategies in pain management in newborn. It can be seen in publications that glucose is the most used solution in interventions. The promotion of pain relief in a newborn should be made by all members of the health team, especially the nursing team, which performs most punctures during the newborn hospitalization. These procedures produce stressful and painful experiences during hospitalization.

\section{Conclusion}

With the analysis of the reviewed studies, it can be said that the research about pain management during arterial, venous and capillary puncture in the newborn showed evidence about the use of glucose as an effective strategy to minimize the pain suffered by the newborn during painful puncture procedures.

It was possible to observe in studies that new interventions are being used such as the use of breast milk, sucrose, winding and the use of scents to promote relief of pain in neonates and infants. 


\section{Collaborations}

Morais APS, Façanha SMA and Rabelo SN contributed to the project design, data collection, analysis and interpretation of data. Silva AVS, Queiroz MVC and Chaves EMC contributed to design, article writing, relevant critical review and final approval of the version to be published.

\section{References}

1. Oliveira LJ, Machado Neto CD. A dor em neonatos submetidos à ventilação mecânica invasiva: uma revisão de literatura. Rev Bras Educ Saúde. 2013; 3(3):1-8.

2. Anand KJS, Phil D, Hickey PR. Pain and its effects in the human neonate and fetus. Engl J Med. 1987; 31(7):1321-9.

3. Silva TM, Chaves EMC, Cardoso MVLML. Dor sofrida pelo recém-nascido durante a punção arterial. Esc Anna Nery. 2009; 13(4):726-32.

4. Guinsburg R. Avaliação e tratamento da dor no recém-nascido. J Pediatr. 1999; 3(75):140-60.

5. Presbytero R, Costa MLV, Santos RCS. Os enfermeiros da unidade neonatal frente ao recémnascido com dor. Rev Rene. 2010; 11(1):125-32.

6. Batalha LMC. Intervenções não farmacológicas no controlo da dor em cuidados intensivos neonatais. Rev Enf Ref. 2010; 3(2):73-80.

7. Amaral JB, Resende TA, Contim DB. Equipe de enfermagem diante da dor do recém-nascido prétermo. Esc Anna Nery. 2014; 18(2):241-6.

8. Bueno M, Costa P, Oliveira AAS, Cardoso R, Kimura AF. Translation and adaptation of the premature infant pain profile into Brazilian Portuguese. Texto Contexto Enferm. 2013; 22(1):29-35.

9. Freitas ZMP, Pereira CU, Oliveira DMP. Escalas para avaliação de dor em neonatologia e sua relevância para a prática de enfermagem. Pediatr Mod. 2012; 68(1):8-24.
10. Oliveira RM, Silva AVS, Silva LMS, Silva APAD, Chaves EMC, Bezerra SC. Implementação de medidas para o alívio da dor em neonatos pela equipe de enfermagem. Esc Anna Nery. 2011; 15(2):277-83.

11. Pimenta PCO, Cherem E, Alves VH, Rodrigues DP. Métodos não farmacológicos para alívio da dor neonatal: revisão integrativa de literatura. Rev Enferm UFSM. 2011; 1(2):261-71.

12. Mendes KDS, Silveira RCCP, Galvão CM. Revisão Integrativa: método de pesquisa para a incorporação de evidências na saúde e na enfermagem. Texto Contexto Enferm. 2008; 17(4):758-64.

13. Melnyk BM, Fineout-Overholt E. Evidence-based practice in nursing \& healthcare: a guide to best practice. Philadelphia: Lippincott Williams \& Wilkins; 2011.

14. American Academic of Pediatrics. Recommends steps to control pain, stress in pediatric emergency care [Internet]. 2012 [cited 2015 Aug 10]. Available from: https://www.aap.org/ en-us/about-the-aap/aap-press-room/pages / AAP-Recommends-Steps-to-Control-Pain-Stressin-Pediatric-Emergency-Care.aspx

13. Caetano EA, Lemos NRF, Cordeiro SM, Pereira FMV, Buchhorn MM. O recém-nascido com dor: atuação da equipe de enfermagem. Esc Anna Nery. 2013; 17(3):439-45.

15. Yilmaz F, Arikan D. The effects of various interventions to newborns on pain and duration of crying. J Clin Nurs. 2010; 20(7-8):1008-17 .

16. Pacheco S, Silva A, Lioi A, Rodrigues T. O cuidado pelo enfermeiro ao recém-nascido prematuro frente à punção venosa. Rev Enferm UERJ. 2012; 20(3):306-11.

17. D'apolito KC. State of the science: procedural pain management in the neonate. J Perinat Neonatal Nurs 2006; 20(1):56-61.

18. Cardoso MVLML, Farias LM, Melo GM. Music and $25 \%$ glucose pain relief for the premature infant: a randomized clinical trial. Rev Latino-Am Enfermagem. 2014; 22(5):810-8. 
19. Simonse E, Mulder PGH, Van BRHT. Analgesic effect of breast milk versus sucrose for analgesia during heel lance in late preterm infants. Pediatrics. 2012; 129(4):657-63.

20. Bueno M, Stevens BCPP, Toma E, Krebs VL, Kimura AF. Breast milk and glucose for pain relief in preterm infants: a noninferiority randomized controlled trial. Pediatrics. 2012; 129(4):664-70.

21. Aquino FM, Christoffel MM. Dor neonatal: medidas não farmacológicas utilizadas pela equipe de enfermagem. Rev Rene. 2010; 11(esp):169-177.
22. NishitanI S, Miymura T, Tagawa M, Sumi M, Takase $\mathrm{R}$, Doi $\mathrm{H}$, et al. The calming effect of a maternal breast milk odor on the human newborn infant. Neurosci Res. 2009; 63(1):66-71.

23. Sadathosseini AS, Negarandeh R, Movahedi Z. The effect of a familiar scent on the behavioral and physiological pain responses in neonates. Pain Manag Nurs. 2013; 14(4):196-203. 